\title{
Effects of corn-based diet starch content and corn particle size on lactation performance, digestibility, and bacterial protein flow in dairy cows
}

\author{
S. M. Fredin, L. F. Ferraretto, M. S. Akins, S. J. Bertics, and R. D. Shaver ${ }^{1}$ \\ Department of Dairy Science, University of Wisconsin-Madison, Madison 53706
}

\begin{abstract}
An experiment was conducted to determine the effects of dietary starch content in corn-based diets and corn particle size on lactation performance, nutrient digestibility, and bacterial protein flow in dairy cows using the omasal and reticular sampling technique. Eight ruminally cannulated lactating multiparous Holstein cows were used in a replicated $4 \times 4$ Latin square design with a $2 \times 2$ factorial arrangement of treatments. Treatments were fine (FG; mean particle size $=552 \mu \mathrm{m})$ and coarse $(\mathrm{CG} ; 1,270 \mu \mathrm{m})$ ground dry shelled corn in normal- (NS) and reduced- (RS) starch diets fed as total mixed rations. The NS and RS rations contained 27 and 18\% starch (dry matter basis), respectively, and were formulated by partially replacing corn with soy hull pellets. Mean dry matter intake was unaffected by treatment $(23.2 \mathrm{~kg} / \mathrm{d})$. Cows fed NS diets produced $1.9 \mathrm{~kg} / \mathrm{d}$ more milk and $0.06 \mathrm{~kg} / \mathrm{d}$ more milk protein compared with cows fed RS diets. Cows fed NSFG and RSCG diets produced more fat-corrected milk than did cows fed NSCG and RSFG diets. Milk urea concentration was decreased for cows fed NS diets $(12.4 \mathrm{mg} / \mathrm{dL})$ compared with RS diets $(13.5 \mathrm{mg} / \mathrm{dL})$. Ruminal digestibility of neutral detergent fiber (NDF; $\%$ of NDF intake) determined by the omasal sampling technique was increased in cows fed RS diets compared with NS diets (43.4 vs. $34.9 \%$ ), and total-tract digestibility of NDF (\% of NDF intake) was increased in cows fed RS diets compared with those fed NS diets (50.1 vs. $43.1 \%$ ). Ruminal digestibility of starch (\% of starch intake) determined by the omasal sampling technique was greater in cows fed NS diets compared with those fed RS diets ( 85.6 vs. $81.6 \%$ ). Total-tract starch digestion was increased in cows fed RS diets compared with those fed NS diets (96.9 vs. 94.6\%) and in cows fed FG diets compared with those fed CG diets (98.0 vs. $93.5 \%$ ). Bacterial protein flow was unaffected by treatment. The omasal and reticular sampling techniques resulted in similar treatment effects for nutrient flow
\end{abstract}

Received June 18, 2014.

Accepted September 16, 2014.

${ }^{1}$ Corresponding author: rdshaver@wisc.edu and digestibility, although nutrient flow was lower and nutrient digestibility was greater in cows when sampled by the omasal technique compared with the reticular technique. Cows fed FG diets had greater ruminal propionate, lower acetate:propionate ratio, and lower $\mathrm{pH}$. Feeding NS diets increased milk and protein yields and feeding finely ground corn increased ruminal propionate concentration.

Key words: corn, lactation, reduced starch, particle size

\section{INTRODUCTION}

Increases in corn prices have increased the interest in feeding reduced-starch diets to lactating dairy cows. Longer term continuous-lactation trials (12 wk) comparing normal- and reduced-starch diets have reported similar or reduced milk yields, similar or greater DMI, similar or reduced milk protein, and similar or reduced feed efficiency ( $\mathrm{kg}$ of milk yield/kg of DMI; Gencoglu et al., 2010; Ferraretto et al., 2011, 2012; Akins et al., 2014) for cows fed corn-based, reduced-starch diets. Estimates of ruminal nutrient digestion and bacterial protein flow when reduced-starch diets are fed may help us better understand the effects of these feeding strategies and allow for dietary adjustments and improvements in animal performance.

Reduced-starch diets typically result in greater total-tract starch digestibility because a greater portion of dietary starch often comes from more digestible feed ingredients such as corn silage (Ferraretto and Shaver, 2012). Starch digestibility is also affected by several factors such as particle size, grain processing, and moisture content (Firkins et al., 2001; Ferraretto et al., 2013). Furthermore, harvest maturity, duration of silo fermentation (Hoffman et al., 2011), and corn endosperm type (Taylor and Allen, 2005; Lopes et al., 2009) influence starch digestibility. Diets with finely ground dry corn grain have improved total-tract starch digestibility, with varying effects on DMI, milk yield, and fat yield (Knowlton et al., 1998; Yu et al., 1998; Rémond et al., 2004). Feeding more digestible corn grain in reduced-starch diets may result in greater milk yield, improved feed efficiency, and similar fat yield 
and animal performance compared with normal-starch diets.

The objectives of this study were to evaluate the effects of feeding normal- or reduced-starch diets and fine or coarse ground dry shelled corn on lactation performance, digestion, bacterial protein flow, and ruminal parameters by dairy cows. We hypothesized that feeding finely ground corn grain compared with coarsely ground corn grain would result in increased milk yield, starch digestibility, and bacterial protein flow. Furthermore, feeding reduced-starch diets compared with normal-starch diets would result in similar FCM yields and increased starch digestibility.

\section{MATERIALS AND METHODS}

\section{Animal Management and Experimental Design}

All experimental protocols were approved by the Animal Care and Use Committee of the College of Agriculture and Life Sciences at the University of Wisconsin-Madison. Eight multiparous Holstein cows averaging $584 \pm 29 \mathrm{~kg}$ of BW and $96 \pm 8 \mathrm{DIM}$ at trial initiation, fitted with ruminal cannulas (Bar Diamond, Parma, ID) measuring $10.2 \mathrm{~cm}$ in diameter, were randomly assigned to a replicated $4 \times 4$ Latin square design with a $2 \times 2$ factorial arrangement of treatments. Experimental periods lasted $21 \mathrm{~d}$ and consisted of a 14-d adaptation period and $7 \mathrm{~d}$ for sample collection. Experimental diets included a normal-starch (NS) ration or a reduced-starch (RS) ration formulated by partially replacing dry ground shelled corn and a small amount of soybean meal with soy hull pellets $(\mathbf{S H})$ to provide isonitrogenous diets. The NS and RS diets contained either finely ground (FG) or coarsely ground (CG) dry shelled corn for experimental diets of NS with FG corn (NSFG), NS with CG corn (NSCG), RS with FG corn (RSFG), and RS with CG corn (RSCG). Ingredient compositions of the experimental diets are in Table 1. Trace minerals and vitamins were supplemented to meet or exceed NRC (2001) guidelines.

Cows were housed on bedded mattresses in a tiestall barn in the Dairy Cattle Center at the University of Wisconsin-Madison. Cows were milked twice daily in a BouMatic Side-Opening single 4 parlor (Boumatic, Madison, WI) at 0700 and $1900 \mathrm{~h}$, with milk yield recorded at each milking for each cow. Milk samples were collected from each cow for 4 consecutive milkings on d 16 and 17 of each treatment period and analyzed for fat, true protein, lactose, and MUN concentrations by infrared analysis (method 972.16; AOAC International, 2012; AgSource Milk Analysis Laboratory, Menomonie, WI) using a Foss Milko-Scan FT6000 (Foss Electric, Hillerød, Denmark). Fat-corrected milk and ECM were calculated from average milk yield during the treatment period and average milk fat and protein content according to NRC (2001). Cows were individually fed a TMR twice daily at 1000 and $1900 \mathrm{~h}$ for a target of $5 \%$ refusals, with the amounts fed and refused recorded daily. The DM contents of alfalfa silage, corn silage, dry ground corn, and NS and RS concentrate mix were determined weekly, with the as-fed proportions adjusted as necessary to maintain the desired DM proportions of the ingredients in the TMR.

\section{Sampling and Laboratory Analysis}

Subsamples of TMR and refusals were collected on d 18 to 20 and d 19 to 21, respectively, for each cow every period. The TMR and refusals and diet ingredients sampled weekly were dried at $60^{\circ} \mathrm{C}$ for $48 \mathrm{~h}$ in a forced-air oven to determine DM content and ground to pass a 1-mm screen using a Wiley mill (model \#4, Thomas Scientific, Swedesboro, NJ). Composites of diet ingredients, TMR for each experimental diet, and refusals for each cow were made by period for analyses

Table 1. Dietary ingredient and nutrient composition

\begin{tabular}{lcc}
\hline Item & $\begin{array}{c}\text { Normal } \\
\text { starch }\end{array}$ & $\begin{array}{c}\text { Reduced } \\
\text { starch }\end{array}$ \\
\hline Ingredient, \% of DM & & \\
Alfalfa silage & 29.5 & 29.9 \\
Corn silage & 22.6 & 22.9 \\
Ground corn grain & 25.2 & 13.2 \\
Concentrate mix & 22.7 & 34.0 \\
Concentrate mix, \% of DM & 11.5 & \\
Soy hulls & 23.4 & 43.8 \\
Soybean meal, 48\% & 27.8 & 12.1 \\
Soybean meal, expeller & & 18.8 \\
Dried distillers grains & 24.7 & 16.8 \\
Partially hydrogenated tallow ${ }^{2}$ & 3.5 & 2.4 \\
Calcium carbonate & 2.29 & 1.53 \\
Sodium bicarbonate & 1.72 & 1.15 \\
Monocalcium phosphate & 1.41 & 0.94 \\
Magnesium oxide & 1.06 & 0.71 \\
Trace mineral salt & & 1.26 \\
Vitamin premix & 1.89 & 0.71 \\
Nutrient composition & 1.06 & \\
DM, \% as fed & & 54.4 \\
CP,\% of DM & 54.8 & 17.3 \\
NDF, \% of DM & 17.1 & 33.8 \\
Forage NDF, \% of DM & 26.5 & 19.9 \\
Ether extract, \% of DM & 19.9 & 3.3 \\
Ash, \% of DM & 3.7 & 8.0 \\
NFC, \% of DM & 7.4 & 37.9 \\
Starch, \% of DM & 45.7 & 18.2 \\
\hline
\end{tabular}

${ }^{1}$ Exceller meal (Quality Roasting Inc., Valders, WI).

${ }^{2}$ Energy Booster (Milk Specialties Global Animal Nutrition, Carpentersville, IL).

${ }^{3} 88 \% \mathrm{NaCl} ; 0.002 \% \mathrm{Co} ; 0.2 \% \mathrm{Cu} ; 0.012 \%$ I; $0.18 \% \mathrm{Fe} ; 0.8 \% \mathrm{Mn}$ $0.006 \%$ Se; $1.4 \% \mathrm{Zn}$.

${ }^{4}$ Vitamin A 3,300,000 IU/kg; vitamin D 1,100,000 IU/kg; vitamin E $11,000 \mathrm{IU} / \mathrm{kg}$.

${ }^{5}$ Calculated as $100-(\mathrm{CP} \%+\mathrm{NDF} \%+$ ether extract $\%+$ ash $\%$; NRC, 2001). 
at a commercial feed testing laboratory (Dairyland Laboratories Inc., Arcadia, WI). Analyses included DM, OM (method 942.05; AOAC International, 2012), CP (method 990.03; AOAC International, 2012), ether extract (method 2003.05; AOAC International, 2012), NDF using $\alpha$-amylase and sodium sulfite (Van Soest et al., 1991), and starch according to Bach Knudsen (1997; Biochemistry Analyzer; YSI Inc., Yellow Springs, $\mathrm{OH})$. Alfalfa silage and corn silage composited by period and $\mathrm{SH}$ obtained before blending of experimental concentrate mixes were analyzed for in vitro NDF digestibility after a 30-h incubation (Holden, 1999). Zein protein was determined on dry corn (Larson and Hoffman, 2008). Composites of ground corn silage and FG and CG dry corn were analyzed for ruminal in vitro starch digestibility after a 7-h incubation (Richards et al., 1995). Particle size of FG and CG dry corn were determined by dry sieving using a Tyler Ro-Tap Shaker (model RX-29, Tyler, Mentor, OH) containing sieves with 4,760-, 2,380-, 1,190-, 595-, 297-, 149-, and 63- $\mu \mathrm{m}$ apertures plus a bottom pan, with the mean particle size calculated using a log normal distribution (Baker and Herrman, 2002).

Digesta flow from the rumen was quantified using omasal sampling (Huhtanen et al., 1997; Ahvenjärvi et al., 2000) and reticular sampling (Krizsan et al., 2010) techniques. The omasal and reticular digesta markers included indigestible NDF (iNDF; Huhtanen et al., 1994) for the large particle phase, $\mathrm{YbCl}_{3}$ (Siddons et al., 1985) for the small particle phase, and Cr-EDTA (Udén et al., 1980) for the fluid phase. The external bacterial marker ${ }^{15} \mathrm{~N}$ was used to measure bacterial $\mathrm{N}$ flows from the rumen. Before the start of infusions, a sample of rumen digesta was collected from each cow and frozen at $-20^{\circ} \mathrm{C}$, lyophilized, and ground to pass a 1-mm screen (Udy mill; Udy Corp., Fort Collins, CO) to determine the natural abundance of ${ }^{15} \mathrm{~N}$. A marker solution containing $3.0 \mathrm{~g} / \mathrm{L}$ of $\mathrm{YbCl}_{3}, 6.0 \mathrm{~g} / \mathrm{L}$ of $\mathrm{Cr}-$ EDTA, and $3.75 \mathrm{~g} / \mathrm{L}$ of ${ }^{15} \mathrm{NH}_{4} \mathrm{SO}_{4}$ with 10 atom percentage excess ${ }^{15} \mathrm{~N}$ (Sigma-Aldrich, St. Louis, MO) was continuously infused at a constant rate of $2.3 \mathrm{~mL} / \mathrm{min}$ for $138 \mathrm{~h}$ from d 15 to 21 using 2 syringe pumps (model 33; Harvard Apparatus Inc., Holliston, MA).

Using the omasal sampling technique, 200-mL spot samples were collected over $4 \mathrm{~d}$ to represent every $2 \mathrm{~h}$ of the 24-h feeding cycle on d 18 to 21. Sampling was at 0600, 0800, 1000, and $1200 \mathrm{~h}$ on d 18; 1400, 1600, 1800, and $2000 \mathrm{~h}$ on d 19; and 2200, 0000, 0200, and $0400 \mathrm{~h}$ on d 20 to 21 . Spot samples of $125 \mathrm{~mL}$ of reticular digesta were obtained immediately after omasal sampling using a plastic container. Omasal and reticular samples were pooled by period for each cow.

The 2.4-L pooled omasal and 1.5-L pooled reticular composites were thawed at room temperature and separated into 3 digesta phases as described by Reynal and Broderick (2005). Samples were squeezed through 1 layer of cheesecloth and particles retained on the cheesecloth were defined as the large particle phase. The filtrate was centrifuged at $1,000 \times g\left(5^{\circ} \mathrm{C}, 5 \mathrm{~min}\right)$, and the supernatant was poured off and kept. The supernatant was defined as the fluid phase and the pellet was defined as the small particle phase. The separated phases were then frozen, lyophilized (Anteco Pharma, Lodi, WI), and ground to pass a 1-mm screen (Wiley mill). Concentrations of $\mathrm{Cr}$ (method 2006.03; AOAC International, 2012) and $\mathrm{Yb}$ (method 985.01; AOAC International, 2012) were determined by inductively coupled plasma optical emission spectrometry at a commercial laboratory (Analabs, Fulton, IL) using a Varian Vista-MPX instrument (Agilent Technologies Inc., Santa Clara, CA). Indigestible NDF was determined in the large particle phase, small particle phase, TMR, and refusals (but not the fluid phase; Ahvenjärvi et al., 2000) according to Krizsan and Huhtanen (2013) with modifications. One-gram samples were weighed into F57 fiber bags (pore size $=25 \mu \mathrm{m}$; Ankom Technology, Macedon, NY) in quadruplicate. Samples were incubated in situ for $288 \mathrm{~h}$ in 2 ruminally cannulated, Holstein, multiparous lactating dairy cows fed a TMR containing (DM basis) alfalfa silage (44.5\%), corn silage $(26.8 \%)$, alfalfa hay $(10.7 \%)$, wheat straw $(6.5 \%)$, and concentrate mixture $(11.5 \%)$. After removal from the rumen, bags were washed in a washing machine for 5 min, dried at $50^{\circ} \mathrm{C}$ for $48 \mathrm{~h}$, and analyzed for NDF as described above. The F57 fiber bags were chosen after initial comparisons between F57 fiber bags and 8- $\mu \mathrm{m}$ pore size polyester bags yielded similar results for iNDF content (data not presented). The F57 fiber bags were premade and designed for use in an Ankom ${ }^{200}$ Fiber Analyzer, thereby reducing labor and costs. Concentrations of $\mathrm{Cr}, \mathrm{Yb}$, and iNDF were used to reconstitute the omasal true digesta flowing out of the rumen based on the triple-marker approach of France and Siddons (1986). Concentrations of $\mathrm{Cr}, \mathrm{Yb}$, and iNDF were greater than those of other markers in the fluid phase, small particle phase, and large particle phase, respectively, allowing for application of the triple-marker approach. Total-tract nutrient digestibilities were determined using iNDF as an internal marker. Six total fecal grab samples were collected from each cow per period on d 18 to 20 every 4 -h clock period to cover a 24-h feeding cycle. Total-tract nutrient digestibilities were calculated from iNDF and nutrient concentration in the refusals-adjusted diet and feces.

Rumen fluid was collected for analysis of $\mathrm{pH}$, VFA concentration, and $\mathrm{NH}_{3}-\mathrm{N}$ concentration immediately after the omasal and reticular samplings. Fluid was collected from the posterior and anterior ventral rumen. 
Rumen $\mathrm{pH}$ was determined immediately using 2 Cardy Twin pH meters (model \#B-213, Spectrum Technologies Inc., Plainfield, IL). Two 1-mL aliquots of rumen fluid were added to microcentrifuge tubes containing $0.02 \mathrm{~mL}$ of $50 \% \mathrm{H}_{2} \mathrm{SO}_{4}$ for later VFA analysis. Rumen VFA concentrations were measured by gas-liquid chromatography (Supelco, 1998). Concentrations of individual VFA were measured on a Clarus 500 gas chromatograph (PerkinElmer, Norwalk, CT) using a 4\% Carbowax $20 \mathrm{M}$ on 80/120 mesh Carbopack-B-DA, $1.8 \mathrm{~mm} \times 2 \mathrm{~mm}$ column (Supelco Inc., Bellefonte, PA) with an oven temperature of $160^{\circ} \mathrm{C}$ and a $\mathrm{N}$ flow rate of $24 \mathrm{~mL} / \mathrm{min}$. Separate duplicate 1-mL aliquots of rumen fluid samples were added to microcentrifuge tubes containing $0.02 \mathrm{~mL}$ of $50 \%$ TCA solution for later analysis of $\mathrm{NH}_{3}-\mathrm{N}$ according to Bal et al. (2000).

During omasal spot sampling, an additional 500$\mathrm{mL}$ sample was collected per day $(125 \mathrm{~mL}$ per spot sampling) for isolation of fluid-associated (FAB) and particle-associated (PAB) bacteria. At the end of each sampling day, the $500-\mathrm{mL}$ omasal composites were squeezed through 1 layer of cheesecloth. Solids retained on the cheesecloth were rinsed with $400 \mathrm{~mL}$ of $0.85 \%$ (wt/vol) $\mathrm{NaCl}$ solution and squeezed again. Filtrates were placed in a refrigerator $\left(5^{\circ} \mathrm{C}\right)$ until processed for isolation of FAB. The solids retained on the cheesecloth were placed in a 1-L bottle containing $350 \mathrm{~mL}$ of cold $\left(5^{\circ} \mathrm{C}\right)$ solution containing $0.85 \%$ (wt/vol) $\mathrm{NaCl}$ and $0.1 \%$ (vol/vol) Tween-80. Bottle contents were mixed thoroughly and placed in a refrigerator $\left(5^{\circ} \mathrm{C}\right)$. Filtrates for $\mathrm{FAB}$ isolation were centrifuged $\left(1,000 \times g, 5^{\circ} \mathrm{C}, 5\right.$ $\mathrm{min})$. Pellets were added to the bottle contents containing $\mathrm{PAB}$, and supernatants were decanted and recentrifuged $\left(11,330 \times g, 5^{\circ} \mathrm{C}, 30 \mathrm{~min}\right)$. These supernatants were discarded and the pellets were resuspended in 100 $\mathrm{mL}$ of McDougall's buffer solution and recentrifuged $\left(11,330 \times g, 5^{\circ} \mathrm{C}, 30 \mathrm{~min}\right)$. Supernatants were then discarded, and the bottle containing FAB was stored at $-20^{\circ} \mathrm{C}$ until lyophilized. Contents of the PAB bottles were blended for $20 \mathrm{~s}$ in a single-speed Waring blender (Waring Products Division, New Hartford, CT), transferred back to the bottles, and stored at $5^{\circ} \mathrm{C}$ overnight. Contents of PAB bottles were then squeezed through 2 layers of cheesecloth and the filtrates were centrifuged $\left(1,000 \times g, 5^{\circ} \mathrm{C}, 5 \mathrm{~min}\right)$. The pellets were discarded and the supernatant was recentrifuged $(11,330 \times g$, $5^{\circ} \mathrm{C}, 30 \mathrm{~min}$ ). Supernatants and final PAB pellets were processed in the same way as FAB.

Samples of FAB, PAB, fluid phase, and the small particle plus large particle phase were prepared for analyses of total NAN and ${ }^{15} \mathrm{~N}$ according to Brito et al. (2006). Approximately $3 \mathrm{mg}$ of bacteria or $6 \mathrm{mg}$ of the small particle plus large particle phase, fluid phase, and background rumen contents were weighed into tin capsules (Elemental Microanalysis Ltd., Okehampton, UK) followed by addition of $50 \mu \mathrm{L}$ of 72 $\mathrm{m} M \mathrm{~K}_{2} \mathrm{CO}_{3}$. Capsules were placed in 96-well microtiter plates and dried in a $55^{\circ} \mathrm{C}$ oven overnight to volatilize ammonia. Samples were analyzed for total $\mathrm{N}$ and ${ }^{15} \mathrm{~N}$ using a Costech 4010 elemental analyzer (Costech Analytical Technologies Inc., Valencia, CA) interfaced to a Thermo-Finnigan Delta-Plus Advantage isotope ratio mass spectrometer (Thermo-Electron GmbH, Bremen, Germany). Calculations of FAB NAN, PAB NAN, total bacterial NAN, RUP flows at the omasum, and RDP supply were made according to Brito et al. (2006). The mean $( \pm \mathrm{SD})$ background ${ }^{15} \mathrm{~N}$ was $0.36703 \pm 0.00009$ atom\%.

At the end of omasal and rumen fluid collections on d 21, feed was removed from cows at approximately $0500 \mathrm{~h}$ for $12 \mathrm{~h}$ to determine dietary effects on serum insulin concentration. Blood samples were collected immediately before refeeding and at 1, 2, 3, 6, and $9 \mathrm{~h}$ postfeeding via coccygeal venipuncture. Blood samples were collected using evacuated sterile tubes for serum (10.0-mL Vacutainer; Becton Dickinson, Franklin Lakes, NJ). After each hourly collection, tubes were immediately brought to the laboratory and centrifuged at $3,000 \times g$ at $4^{\circ} \mathrm{C}$ for $20 \mathrm{~min}$ for isolation of serum and stored at $-20^{\circ} \mathrm{C}$ until analyzed for insulin. Serum insulin concentrations were determined using an ELISA kit (ALPCO Diagnostics, Salem, NH), and inter- and intraassay coefficients of variation were 6.1 and $4.3 \%$, respectively. Insulin responses were reported as mean insulin concentrations subtracted from the baseline concentration over time and as area under the curve (AUC) through the 9-h sample.

\section{Statistical Analysis}

Data were analyzed using the mixed procedure of SAS (ver. 9.2, SAS Institute Inc., Cary, NC) for a replicated $4 \times 4$ Latin square design according to the following model:

$$
\begin{aligned}
\mathrm{Y}_{\mathrm{ijkl}}=\mu & +\mathrm{S}_{\mathrm{i}}+\mathrm{P}_{\mathrm{j}}+\mathrm{C}_{\mathrm{k}(\mathrm{i})}+\mathrm{T}_{\mathrm{l}}+\mathrm{M}_{\mathrm{m}} \\
& +\mathrm{ST}_{\mathrm{il}}+\mathrm{TM}_{\mathrm{lm}}+\mathrm{E}_{\mathrm{ijkl}},
\end{aligned}
$$

where $Y_{\mathrm{ijkl}}$ was the dependent variable, $\mu$ was the overall mean, $S_{i}$ was the fixed effect of square $i, P_{j}$ was the fixed effect of period $\mathrm{j}, \mathrm{C}_{\mathrm{k}(\mathrm{i})}$ was the random effect of cows $\mathrm{k}$ (within square $\mathrm{i}$ ), $\mathrm{T}_{1}$ was the fixed effect of treatment $\mathrm{l}$, $\mathrm{M}_{\mathrm{m}}$ was the fixed effect of sampling method $\mathrm{m}, \mathrm{ST}_{\mathrm{il}}$ was the interaction between square $\mathrm{i}$ and treatment $\mathrm{l}, \mathrm{TM}_{\mathrm{lm}}$ was the interaction between treatment and sampling method, and $\mathrm{E}_{\mathrm{ijkl}}$ was the residual error. Ruminal data were analyzed with time as repeated measure using the 
first-order autoregressive covariance structure, which provided the best fit according to Sawa's Bayesian information criterion. Degrees of freedom were calculated using the Kenward-Roger option. Preplanned contrasts were included to compare NS and RS, FG and CG corn grain, and the interaction between dietary starch concentration and corn grain particle size. The least squares means statement was used to determine treatment means. Significance was declared at $P \leq 0.05$ and trends at $0.05<P \leq 0.10$.

\section{RESULTS AND DISCUSSION}

Nutrient composition of the diets and ingredients are in Tables 1 and 2, respectively. The NS and RS diets averaged 26.5 and $18.2 \%$ starch, respectively. Partial replacement of corn grain with $\mathrm{SH}$ in the RS diet increased the NDF content from 26.5 to $33.8 \%$. Dietary ash content averaged 7.4 and $8.0 \%$, and ether extract content averaged 3.7 and $3.3 \%$ for NS and RS diets, respectively, due to the greater ash content and lesser ether extract content of SH compared with corn grain (Table 2). Forage NDF was $19.9 \%$ for all diets. All other nutrients were similar among the experimental diets. The mean particle size of the FG and CG corn grain was 552 and $1,270 \mu \mathrm{m}$, respectively, and the zein content of the corn grain used to prepare FG and CG was $35.2 \pm 1.8 \mathrm{~g} / 100 \mathrm{~g}$ of $\mathrm{CP}$ (data not provided in Table).

Treatment effects for DMI, milk yield, and milk composition are in Table 3. Dry matter intake did not differ for dietary starch content or corn particle size $(P$ $>0.10$ ). Other researchers (Ipharraguerre et al., 2002; Ferraretto et al., 2012; Akins et al., 2014) have reported that DMI was unaffected when SH partially replaced corn grain, but DMI was increased when SH partially replaced corn grain in the study of Gencoglu et al. (2010). In continuous lactation trials, Yu et al. (1998) found that DMI decreased for cows fed a diet containing FG corn (mean particle size $=1,180$ vs. $2,420 \mu \mathrm{m}$ ), whereas Knowlton et al. (1998; exp. 2) reported that DMI was increased for cows fed diets containing FG corn $($ mean particle size $=618$ vs. $1,725 \mu \mathrm{m})$. Furthermore, DMI was unaffected with differing corn particle sizes in the Latin square studies of Knowlton et al. (1998; exp. 1) and Rémond et al. (2004; mean particle size $=700,1,800$, and $3,700 \mu \mathrm{m}$ for exp. 1 and $600 \mathrm{vs}$. $3,500 \mu \mathrm{m}$ for exp. 2).

Milk yield was greater for the NS diets compared with the RS diets ( 41.0 vs. $39.1 \mathrm{~kg} / \mathrm{d} ; P=0.03$ ). Milk yield was unaffected when corn grain was partially replaced by $\mathrm{SH}$ in several studies (Ipharraguerre et al., 2002; Gencoglu et al., 2010; Ferraretto et al., 2012). However, Akins et al. (2014) reported greater milk yield for cows fed a NS diet. Milk yield was unaffected by differing corn grain particle size $(P>0.10)$. The literature is controversial in regard to the effects of corn grain particle size on milk yield, with similar (Knowlton et al., 1998, exp. 1; Yu et al., 1998) or increased (Knowlton et al., 1998, exp. 2; Rémond et al., 2004) milk yield for cows fed diets containing FG corn compared with CG corn. In a meta-analysis by Firkins et al. (2001), milk yield was increased $1.0 \mathrm{~kg} / \mathrm{d}$ for diets containing dry fine-ground compared with dry-rolled corn, but this was not observed in a more recent meta-analysis by Ferraretto et al. (2013).

Milk fat content tended to be increased for cows fed the RS diets $(P=0.10)$ but milk protein and lactose contents were unaffected by dietary starch content. Milk fat yield tended to be greater for the NSFG and RSCG diets $(P=0.06)$, and milk protein yield was greater for cows fed the NS diets $(P=0.01)$. The tendency for increased milk fat content and yield for cows fed the NSFG and RSCG diets resulted in increased FCM yield $(P=0.05)$. Ferraretto et al. (2012) reported a tendency for increased milk fat content for cows fed

Table 2. Ingredient nutrient composition (\% of DM unless otherwise noted)

\begin{tabular}{|c|c|c|c|c|c|c|c|}
\hline Nutrient & $\begin{array}{c}\text { Corn } \\
\text { silage }\end{array}$ & $\begin{array}{l}\text { Alfalfa } \\
\text { silage }\end{array}$ & $\begin{array}{c}\text { Normal-starch } \\
\text { concentrate }\end{array}$ & $\begin{array}{l}\text { Reduced-starch } \\
\text { concentrate }\end{array}$ & $\begin{array}{l}\text { Fine-ground } \\
\text { corn }\end{array}$ & $\begin{array}{l}\text { Coarse-ground } \\
\text { corn }\end{array}$ & $\begin{array}{l}\text { Soy } \\
\text { hulls }\end{array}$ \\
\hline DM, $\%$ as fed & 41.3 & 47.6 & 91.7 & 90.6 & 91.0 & 91.0 & 92.1 \\
\hline $\mathrm{CP}$ & 7.7 & 19.5 & 32.9 & 25.5 & 8.4 & 8.4 & 11.7 \\
\hline Ether extract & 3.3 & 3.0 & 5.0 & 3.4 & 3.7 & 3.7 & 1.8 \\
\hline Ash & 4.4 & 10.4 & 13.6 & 11.1 & 1.3 & 1.3 & 5.0 \\
\hline Starch & 38.9 & - & - & - & 70.3 & 70.3 & - \\
\hline IVSD ${ }^{3} \%$ of starch & 69.9 & - & - & - & 52.3 & 32.1 & - \\
\hline Mean particle size, $\mu \mathrm{m}$ & - & - & - & - & 552 & 1,270 & - \\
\hline
\end{tabular}

${ }^{1}$ Calculated as $100-(\mathrm{CP} \%+\mathrm{NDF} \%+$ ether extract $\%+$ ash \%; NRC, 2001).

${ }^{2}$ IVNDFD $=$ in vitro NDF digestibility after $30-\mathrm{h}$ incubation.

${ }^{3} \mathrm{IVSD}=$ in vitro starch digestibility after 7 -h incubation. 
Table 3. Effects of dietary starch content and corn particle size on lactation performance

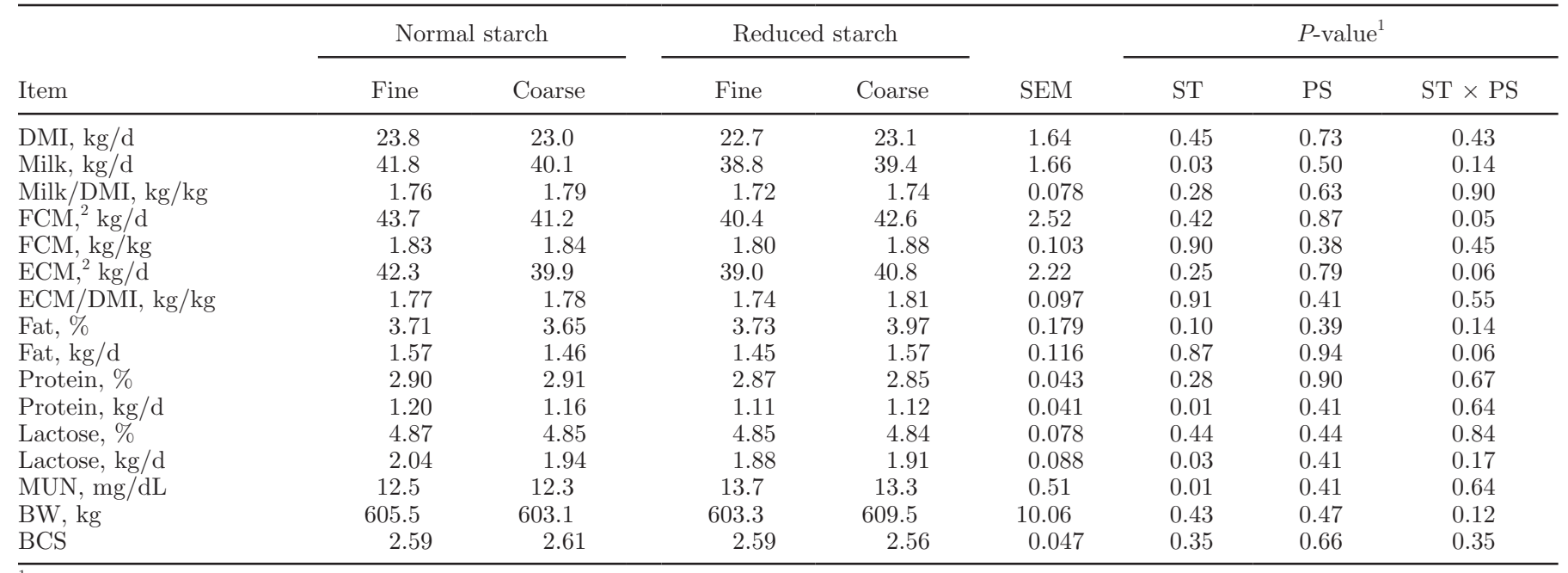

${ }^{1} \mathrm{ST}=$ starch; $\mathrm{PS}=$ particle size.

${ }^{2} 4.0 \% \mathrm{FCM}$ yield $=(0.4 \times \mathrm{kg}$ of milk $)+(15.0 \times \mathrm{kg}$ of fat $) ; \mathrm{ECM}$ yield $=(12.86 \times \mathrm{kg}$ of fat $)+(7.04 \times \mathrm{kg}$ of protein $)+(0.325 \times \mathrm{kg}$ of milk $) ;$ NRC (2001).

a RS diet; however, milk fat content was unaffected in several studies (Ipharraguerre et al., 2002; Gencoglu et al., 2010; Akins et al., 2014). Milk protein content has been reported to decrease (Akins et al., 2014), to tend to decrease (Gencoglu et al., 2010), or to remain unaffected (Ipharraguerre et al., 2002; Ferraretto et al., 2012) for cows fed RS diets. Firkins et al. (2001) reported that milk fat and protein contents were greater for CG dry corn, whereas Ferraretto et al. (2013) reported that milk fat and protein content were unaffected by corn grain particle size. Milk urea-N was reduced for cows fed the NS diets $(P=0.01)$. The MUN concentrations have been consistently lower for cows fed NS diets compared with RS diets (Ipharraguerre et al., 2002; Gencoglu et al., 2010; Ferraretto et al., 2012; Akins et al., 2014). Ferraretto et al. (2013) found that MUN concentrations tended to increase with increasing mean particle size. The relative difference between the corn grain particle sizes (552 vs. 1,270 $\mu \mathrm{m}$ ) in the present study was less than the relative differences between particle sizes used in several other studies, which may have limited the detection of treatment differences for milk and component yields. However, the difference in corn grain particle size in the present study is similar to the variation typically observed among dairy farms. Tassoul et al. (2007) collected dry corn from 11 dairy farms and found that particle size ranged from 407 to $1,049 \mu \mathrm{m}$, and that $12-\mathrm{h}$ rumen in vitro starch digestibility ranged from 49 to $74 \%$ of starch.

Apparent total-tract digestion of $\mathrm{DM}$ and $\mathrm{OM}$ and apparent ruminal digestion of $\mathrm{OM}$ results are given in Table 4. Total-tract digestion of DM and OM were unaffected by treatment $(P>0.15)$. Apparent ruminal digestion of OM (\% of intake) was unaffected using the omasal sampling technique ( mean $=33.0 \% ; P>0.15)$. Huhtanen et al. (2010) reported that apparent ruminal digestibility of OM ranged from 35.1 to $63.8 \%$ (mean $=47.2 \%$ ) in a meta-analysis using the omasal sampling technique in cattle. The low apparent ruminal digestibility of OM reported in the present study is likely due to the greater than expected OM flow $(14.2 \mathrm{~kg} / \mathrm{d}$; Table 4). Apparent ruminal digestion of $\mathrm{OM}$ tended to be greater on the NS diets when sampled using the reticular technique $(P=0.09)$. Ipharraguerre et al. (2002) found that total-tract DM and OM digestibility (as a $\%$ of intake) and apparent ruminal digestibility of $\mathrm{OM}$ were unaffected when SH partially replaced 10 to $30 \%$ of the corn grain in diet DM. Knowlton et al. (1998) reported greater total-tract DM digestibility for cows fed FG corn. Similarly, Rémond et al. (2004) reported greater apparent ruminal (exp. 1 only) and total-tract OM digestibility for cows fed FG corn, whereas Yu et al. (1998) found that total-tract OM digestibility was unaffected by particle size.

Treatment effects on NDF intake and apparent ruminal and total-tract digestion are given in Table 5. Apparent ruminal digestion of $\mathrm{NDF}(P<0.01)$, potentially digestible NDF (pdNDF; $P \leq 0.02$ ), and ruminal outflow of NDF $(P \leq 0.02)$ and pdNDF $(P=$ $0.01)$ were greater for cows fed the RS diets with both sampling techniques. Similarly, total-tract digestion of NDF was greater for cows fed the RS diets $(P=0.01)$. Flow of NDF out of the rumen tended $(P=0.06)$ to be greater for the FG diets when sampling with the omasal technique. Total-tract digestion of NDF was reduced in cows fed the NS diets $(P \leq 0.01)$. Huhtanen 
Table 4. Effects of dietary starch content and corn particle size on digestion of DM and OM

\begin{tabular}{|c|c|c|c|c|c|c|c|c|}
\hline Item & \multicolumn{2}{|c|}{ Normal starch } & \multicolumn{2}{|c|}{ Reduced starch } & SEM & \multicolumn{3}{|c|}{$P$-value ${ }^{1}$} \\
\hline \multicolumn{9}{|l|}{$\mathrm{DM}$} \\
\hline Apparent total-tract digestion, $\%$ & 69.1 & 67.0 & 67.4 & 67.5 & 1.06 & 0.53 & 0.28 & 0.25 \\
\hline \multicolumn{9}{|l|}{$\mathrm{OM}$} \\
\hline Intake, $\mathrm{kg} / \mathrm{d}$ & 22.08 & 21.32 & 20.93 & 21.21 & 1.166 & 0.34 & 0.71 & 0.43 \\
\hline \multicolumn{9}{|l|}{ Omasal sampling } \\
\hline Flow at omasum, kg/d & 14.60 & 13.68 & 14.20 & 14.15 & 0.679 & 0.92 & 0.24 & 0.29 \\
\hline \multicolumn{9}{|l|}{ Reticular sampling } \\
\hline Apparent ruminal digestion, $\mathrm{kg} / \mathrm{d}$ & 5.84 & 6.22 & 4.67 & 5.49 & 1.061 & 0.08 & 0.26 & 0.67 \\
\hline Apparent ruminal digestion, $\%$ & 25.9 & 27.6 & 21.5 & 24.7 & 3.22 & 0.09 & 0.25 & 0.72 \\
\hline Flow at reticulum, $\mathrm{kg} / \mathrm{d}$ & 16.23 & 15.11 & 16.26 & 15.72 & 0.671 & 0.47 & 0.07 & 0.51 \\
\hline Apparent total-tract digestion, $\mathrm{kg} / \mathrm{d}$ & 15.70 & 15.60 & 14.59 & 14.78 & 1.094 & 0.31 & 0.32 & 0.16 \\
\hline
\end{tabular}

${ }^{1} \mathrm{ST}=$ starch; PS $=$ particle size.

et al. (2010) reported that apparent ruminal digestion of NDF (\% of intake) ranged from 27.0 to $80.9 \%$ $($ mean $=55.1 \%)$ in studies using the omasal sampling technique. Similar to the results for ruminal OM digestion, values for ruminal NDF digestion (\% of intake) in the present study (mean $=39.1 \%$ ) may be lesser than expected due to greater than expected NDF flow out of the rumen. Total-tract NDF digestibility was increased for RS diets in the studies of Gencoglu et al. (2010) and Ferraretto et al. (2012), whereas ruminal and total-tract NDF digestibilities were unaffected in the study of Ipharraguerre et al. (2002). When highfiber byproducts, such as $\mathrm{SH}$, are used to partly replace corn grain, dietary NDF content increases and digestibility of dietary NDF increases because of the low lignin content of the NDF in SH (Ipharraguerre and Clark, 2003). Furthermore, reduced dietary starch concentrations have been reported to increase ruminal and total-tract NDF digestibilities (Firkins et al., 2001; Ferraretto et al., 2013).

Treatment effects on starch intake and ruminal and total-tract digestion are shown in Table 6. Apparent ruminal digestion of starch (as a \% of starch intake) was greater for cows fed the NS diets $(P \leq 0.02)$ with both sampling techniques. Unexpectedly, ruminal digestion of starch was greater $(P=0.01)$ when sampled by the reticular technique or tended to be greater $(P$ $=0.10)$ when sampled by the omasal technique for the CG diets. In studies using duodenally cannulated cows for measurements of starch flow, Knowlton et al. (1998) reported that coarser corn particle size resulted in increased ruminal starch digestion, whereas Rémond et al. (2004) found the opposite effect. Firkins et al. (2001) reported that apparent ruminal digestibility of starch from studies using duodenally cannulated cows to measure starch flow averaged $47.0 \%$ in diets containing dry-rolled corn. Similarly, Ferraretto et al. (2013) reported that apparent ruminal starch digestibility from studies using duodenally cannulated cows averaged $53.5 \%$ in diets containing dry ground or rolled corn. Ipharraguerre et al. (2007) compared ruminal starch digestibility measured by the omasal or duodenal sampling technique. Ruminal starch digestibility was substantially greater for cows sampled by the omasal technique (86.0\%) compared with the duodenal technique ( -40.0 to $9.0 \%$ ). The negative ruminal starch digestibilities measured by the duodenal sampling technique were likely caused by discharge of dense corn particles during digesta collection due to increased intensity and frequency of abomasal contractions resulting in overestimates of duodenal starch flow (Robinson and Kennelly, 1990; Ipharraguerre et al., 2007). The overestimates of starch flow and corresponding underestimates of ruminal starch digestibility did not occur with omasal sampling and explain the increase in ruminal starch digestibility observed when digesta were collected by the omasal technique compared with estimates from duodenal sampling (Ipharraguerre et al., 2007). Total-tract starch digestion was increased for cows fed RS $(P=0.02)$ and FG $(P<0.01)$ diets, which agrees with previous results for RS (Gencoglu et al., 2010; Ferraretto et al., 2012) and FG diets (Knowlton et al., 1998; Yu et al., 1998; Rémond et al., 2004).

A comparison of nutrient digestibility and flow for the omasal and reticular sampling techniques is given in Table 7. Apparent digestibilities (as $\mathrm{kg} / \mathrm{d}$ or as \% of $\mathrm{DM}$ ) of OM, NDF, pdNDF, and starch were greater when using the omasal technique compared with the reticular technique $(P \leq 0.04)$, due to the reduced flow of all nutrients $(P \leq 0.03)$ caused by an increased concen- 
Table 5. Effects of dietary starch content and corn particle size on digestion of total and potentially digestible NDF

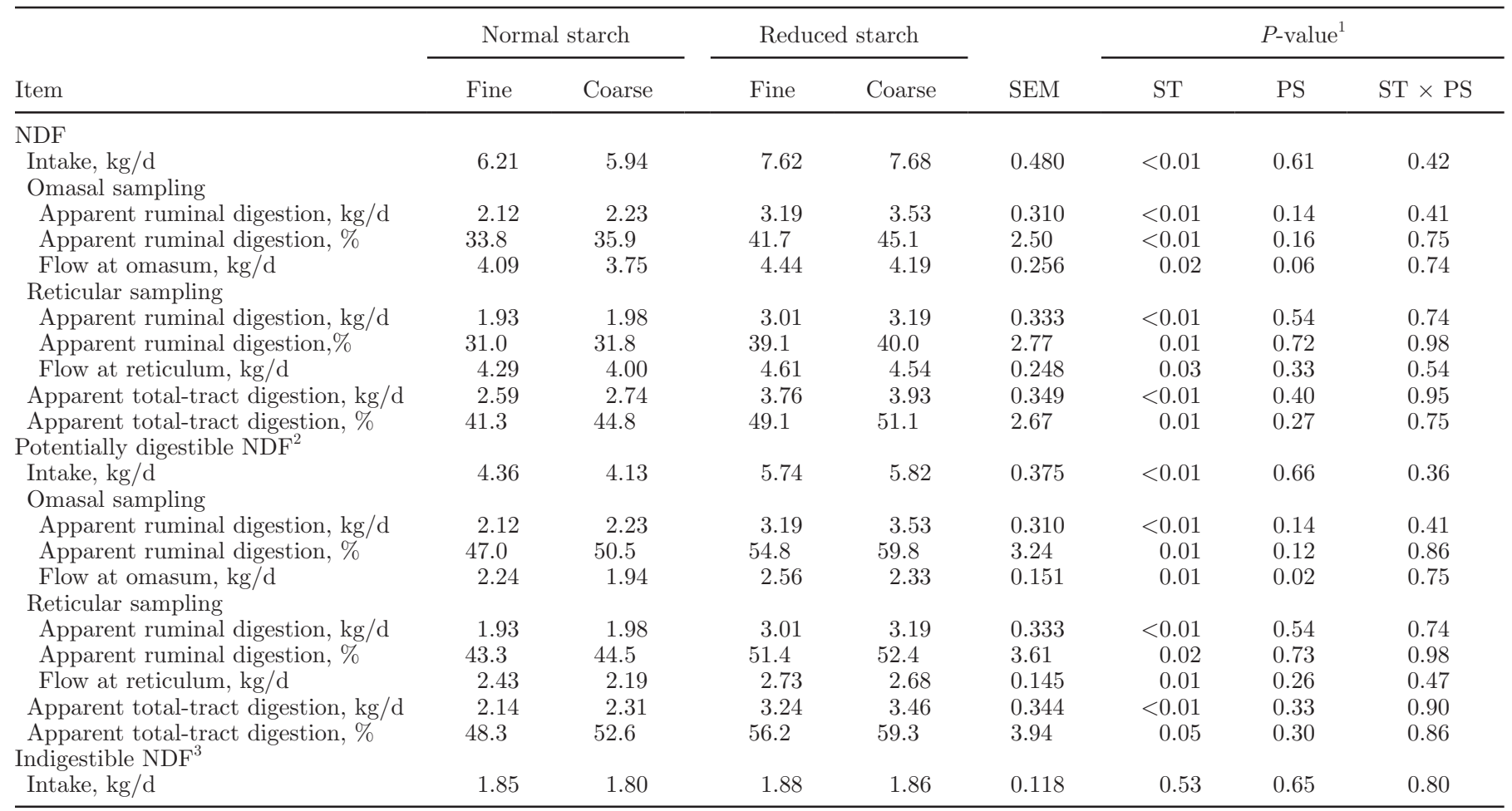

${ }^{1} \mathrm{ST}=$ starch; PS $=$ particle size.

${ }^{2}$ Potentially digestible NDF $=\mathrm{NDF}-$ indigestible NDF.

${ }^{3}$ Indigestible NDF $=$ NDF residue remaining after a 288-h rumen in situ incubation.

tration of markers in the 3 phases when sampled using the omasal technique. Krizsan et al. (2010) compared omasal and reticular sampling techniques in cows fed grass silage-based diets and found that marker concentration did not differ by sampling site and gave similar results for ruminal digestibility and flow of DM, OM, starch, and N. However, Krizsan et al. (2010) collected digesta from the reticulum $3 \mathrm{~h}$ after omasal collection, whereas reticular digesta were collected immediately after omasal sampling in the present study. Furthermore, Krizsan et al. (2010) fractionated the reticular sample by manually filtering the sample through a $1,000-\mu \mathrm{m}$ sieve and discarded the particles retained on the sieve. This step was excluded in the present study because it was thought that the omasal and reticular true digesta could be reconstituted from the large particle phase,

Table 6. Effects of dietary starch content and corn particle size on starch intake and digestion

\begin{tabular}{|c|c|c|c|c|c|c|c|c|}
\hline \multirow[b]{2}{*}{ Item } & \multicolumn{2}{|c|}{ Normal starch } & \multicolumn{2}{|c|}{ Reduced starch } & \multirow[b]{2}{*}{ SEM } & \multicolumn{3}{|c|}{$P$-value ${ }^{1}$} \\
\hline & Fine & Coarse & Fine & Coarse & & $\mathrm{ST}$ & PS & $\mathrm{ST} \times \mathrm{PS}$ \\
\hline \multicolumn{9}{|l|}{ Omasal sampling } \\
\hline Apparent ruminal digestion, $\mathrm{kg} / \mathrm{d}$ & 5.36 & 5.34 & 3.29 & 3.43 & 0.357 & $<0.01$ & 0.75 & 0.68 \\
\hline Apparent ruminal digestion, $\%$ & 84.4 & 86.7 & 79.9 & 83.2 & 1.64 & 0.02 & 0.10 & 0.79 \\
\hline \multicolumn{9}{|l|}{ Reticular sampling } \\
\hline Apparent ruminal digestion, $\mathrm{kg} / \mathrm{d}$ & 5.04 & 5.14 & 2.98 & 3.27 & 0.360 & $<0.01$ & 0.27 & 0.58 \\
\hline Apparent ruminal digestion, $\%$ & 79.2 & 83.7 & 71.8 & 78.0 & 1.99 & $<0.01$ & 0.01 & 0.57 \\
\hline Flow at reticulum, $\mathrm{kg} / \mathrm{d}$ & 1.31 & 1.00 & 1.13 & 0.89 & 0.079 & 0.05 & $<0.01$ & 0.58 \\
\hline Apparent total-tract digestion, $\mathrm{kg} / \mathrm{d}$ & 6.23 & 5.57 & 4.03 & 3.99 & 0.350 & $<0.01$ & 0.03 & 0.06 \\
\hline Apparent total-tract digestion, $\%$ & 98.1 & 91.1 & 97.9 & 95.8 & 0.85 & 0.02 & $<0.01$ & 0.01 \\
\hline Fecal starch concentration, \% & 1.6 & 7.0 & 1.2 & 2.3 & 0.52 & $<0.01$ & $<0.01$ & $<0.01$ \\
\hline
\end{tabular}

${ }^{1} \mathrm{ST}=$ starch PS $=$ particle size 
small particle phase, and fluid phase by calculation from the marker concentrations. Manually filtering the reticular samples for particles $>1,000 \mu \mathrm{m}$ would likely reduce the amount of digestible $\mathrm{OM}$ or pdNDF within the digesta sample. By selectively discarding larger particles containing digestible $\mathrm{OM}$ or pdNDF, the final concentration of the markers may increase in the reticular samples. Manually filtering the reticular digesta through a $1,000-\mu \mathrm{m}$ screen to reduce excessively long particles in the sample before further analysis is advised. Hristov (2007) compared ruminal nutrient flow and digestibility by reticular or duodenal sampling for cows primarily fed alfalfa hay, grass hay, corn grain, and barley grain. Ruminal digestibilities of DM (60.4 vs. $54.1 \%)$ and $\mathrm{OM}$ (69.3 vs. $61.3 \%$ ) were greater when using the reticular technique compared with duodenal sampling, whereas ruminal NDF digestibility (43.2 compared with $50.5 \%$ ) was reduced when sampled using the reticular technique (Hristov, 2007). Ruminal starch digestibility was 68.0 and $65.1 \%$ for reticular and duodenal sampling, respectively, and was unaffected by sampling technique (Hristov, 2007). Although differences exist between omasal or duodenal compared with reticular sampling, the relatively minor differences reported in previous literature and the capability to detect similar treatment effects for ruminal nutrient flow and digestibility between sampling techniques suggest that the reticular technique is a viable alternative to the more expensive sampling techniques.

Treatment effects for omasal flow of $\mathrm{N}$ fractions are given in Table 8 . Nitrogen intake was unaffected by diet $(P>0.10 ;$ mean $=638 \mathrm{~g} / \mathrm{d})$. Flow of NAN was unaffected by $\operatorname{diet}(P>0.10$; mean $=755 \mathrm{~g} / \mathrm{d})$; however, flow of NAN was $18 \%$ greater than N intake, suggesting that measurements of DM flow were overestimated. Flows of FAB NAN (mean $=193 \mathrm{~g} / \mathrm{d}$ ) and PAB NAN $($ mean $=271 \mathrm{~g} / \mathrm{d})$ were unaffected by $\operatorname{diet}(P>0.10)$. Flow of total bacterial NAN $(P=0.06)$ and RUP $(P$ $=0.07)$ tended to increase for cows fed the NSFG and RSCG diets compared with those fed the NSCG and RSFG diets. Total bacterial NAN (\% of NAN) was increased for cows fed the NS diets $(P=0.03)$ and tended to increase for cows fed the CG diets $(P=0.07)$. We detected no effect of diet on NAN content (\% of $\mathrm{DM})$ or the concentration of ${ }^{15} \mathrm{~N}$ above the background concentration of ${ }^{15} \mathrm{~N}$ (described as ${ }^{15} \mathrm{~N}$ atom $\%$ excess) for FAB, PAB, or FP $(P>0.10$; Table 9$)$. Nonammonia $\mathrm{N}$ content increased in the small particle plus large particle phase for cows fed NS $(P=0.03)$ and $C G$ diets $(P$ $=0.04$ ), similar to increases in total bacterial NAN on the NS and CG diets (Table 8). Bacterial protein synthesis increases as ruminally digestible OM increases (Broderick et al., 2010) and apparent digestibility of OM was greater for cows fed the NS diets and tended to increase for cows fed the CG diets in the current study (Table 6). Furthermore, CG diets resulted in greater ruminal starch digestibility than FG diets, leading to greater amounts of rumen fermentable carbohydrate to support bacterial protein synthesis.

Treatment effects for mean ruminal $\mathrm{pH}, \mathrm{NH}_{3}-\mathrm{N}$ concentration, total VFA concentration, and VFA molar proportions are in Table 10. Rumen $\mathrm{pH}$ was greater on the $\mathrm{CG}$ diets $(P=0.04)$. Rumen $\mathrm{NH}_{3}-\mathrm{N}(\mathrm{mg} / \mathrm{dL})$ and total VFA $(\mathrm{m} M)$ were unaffected by treatment $(P>$ $0.10)$. The molar proportion of rumen propionate was increased on the FG diets $(P=0.001)$, whereas molar

Table 7. Comparison of apparent nutrient digestibility and flow between the omasal and reticular sampling techniques

\begin{tabular}{|c|c|c|c|c|c|}
\hline \multirow[b]{2}{*}{ Item } & \multicolumn{2}{|c|}{ Sampling site } & \multirow[b]{2}{*}{ SEM } & \multicolumn{2}{|c|}{$P$-value ${ }^{1}$} \\
\hline & Omasum & Reticulum & & Site & Site $\times$ Diet \\
\hline \multicolumn{6}{|l|}{$\mathrm{OM}$} \\
\hline Apparent ruminal digestion, $\mathrm{kg} / \mathrm{d}$ & 7.23 & 5.55 & 0.949 & $<0.01$ & 0.23 \\
\hline Apparent ruminal digestion, $\%$ & 33.0 & 24.9 & 2.44 & $<0.01$ & 0.32 \\
\hline Flow, kg/d & 14.16 & 15.83 & 0.579 & $<0.01$ & 0.23 \\
\hline \multicolumn{6}{|l|}{$\mathrm{NDF}$} \\
\hline Apparent ruminal digestion, $\mathrm{kg} / \mathrm{d}$ & 2.77 & 2.53 & 0.293 & 0.03 & $<0.01$ \\
\hline Apparent ruminal digestion, $\%$ & 39.1 & 35.4 & 1.98 & 0.01 & $<0.01$ \\
\hline Flow, $\mathrm{kg} / \mathrm{d}$ & 4.12 & 4.36 & 0.213 & 0.03 & 0.01 \\
\hline \multicolumn{6}{|l|}{ Potentially digestible NDF } \\
\hline Apparent ruminal digestion, $\mathrm{kg} / \mathrm{d}$ & 2.77 & 2.53 & 0.293 & 0.03 & $<0.01$ \\
\hline Apparent ruminal digestion, $\%$ & 52.8 & 47.9 & 2.58 & 0.01 & 0.01 \\
\hline Flow, kg/d & 2.27 & 2.51 & 0.114 & 0.01 & $<0.01$ \\
\hline \multicolumn{6}{|l|}{ Starch } \\
\hline Apparent ruminal digestion, $\mathrm{kg} / \mathrm{d}$ & 4.36 & 4.10 & 0.329 & 0.04 & $<0.01$ \\
\hline Apparent ruminal digestion, $\%$ & 83.5 & 78.2 & 1.22 & $<0.01$ & 0.01 \\
\hline Flow, $\mathrm{kg} / \mathrm{d}$ & 0.83 & 1.08 & 0.055 & $<0.01$ & 0.02 \\
\hline
\end{tabular}

${ }^{1}$ Site $=$ omasum or reticulum; Diet $=$ normal starch, reduced starch, fine-ground corn grain, and coarse-ground corn grain. 
Table 8. Effects of dietary starch content and corn particle size on omasal flow of $\mathrm{N}$ fractions

\begin{tabular}{|c|c|c|c|c|c|c|c|c|}
\hline Item $^{1}$ & \multicolumn{2}{|c|}{ Normal starch } & \multicolumn{2}{|c|}{ Reduced starch } & SEM & \multicolumn{3}{|c|}{$P$-value ${ }^{2}$} \\
\hline \multicolumn{9}{|l|}{ Nitrogen } \\
\hline Flow of NAN at omasum, g/d & 785 & 745 & 721 & 768 & 33.1 & 0.29 & 0.86 & 0.04 \\
\hline Apparent total-tract digestion, $\mathrm{kg} / \mathrm{d}$ & 426 & 411 & 413 & 416 & 31.8 & 0.77 & 0.68 & 0.55 \\
\hline Apparent total-tract digestion, $\%$ & 65.6 & 65.4 & 65.4 & 65.2 & 1.22 & 0.86 & 0.85 & 0.97 \\
\hline \multicolumn{9}{|l|}{ PAB NAN flow } \\
\hline $\mathrm{g} / \mathrm{d}$ & 284 & 274 & 251 & 276 & 14.8 & 0.16 & 0.49 & 0.11 \\
\hline$\%$ of total bacteria NAN & 58.9 & 58.5 & 59.7 & 58.2 & 1.13 & 0.55 & 1.00 & 0.77 \\
\hline \multicolumn{9}{|l|}{ Total bacterial NAN } \\
\hline $\mathrm{g} / \mathrm{d}$ & 484 & 468 & 434 & 472 & 21.9 & 0.11 & 0.44 & 0.06 \\
\hline$\%$ of NAN & 61.6 & 62.8 & 60.0 & 61.3 & 0.88 & 0.03 & 0.07 & 0.94 \\
\hline
\end{tabular}

${ }^{1} \mathrm{FAB}=$ fluid-associated bacteria; $\mathrm{PAB}=$ particle-associated bacteria.

${ }^{2} \mathrm{ST}=$ starch $; \mathrm{PS}=$ particle size.

proportions of isobutyrate $(P=0.01)$ and 3-methylbutyrate $(P<0.01)$ and acetate:propionate ratio $(P$ $<0.01)$ were reduced on the FG diets. Most studies have reported no influence of grain particle size on rumen pH (Knowlton et al., 1996, 1998; Rémond et al., 2004). However, as corn particle size is reduced, ruminal starch digestibility is typically increased (Ferraretto et al., 2013) and rumen total VFA concentration is increased, thereby potentially leading to lower $\mathrm{pH}$. Rumen propionate was unaffected in the studies of Knowlton et al. (1998) and Rémond et al. (2004). Few studies have reported effects of corn grain particle size on branched-chain VFA. Knowlton et al. (1996) reported that concentrations of branched-chain VFA were increased for cows fed CG diets, and Taylor and
Allen (2005) found that branched-chain VFA tended to increase when a vitreous corn hybrid replaced a floury and more ruminally digestible corn hybrid. Decreased ruminal $\mathrm{pH}$, increased ruminal propionate, and reduced acetate:propionate ratio for cows fed the FG diets would suggest a greater ruminal starch digestibility for the FG diets compared with CG diets. However, ruminal starch digestibility was greater for cows fed the CG diets in the present study (Table 6). The contradictory ruminal parameters and ruminal starch digestibility data may suggest both a faster rate of digestion and flow for the FG corn grain. The increased rate of ruminal starch digestibility of FG corn grain can result from increased surface area for bacterial attachment and enzymatic digestion (Nocek and Tamminga, 1991; Huntington,

Table 9. Effects of reduced starch content and corn particle size on composition and isotopic enrichment of rumen bacteria

\begin{tabular}{|c|c|c|c|c|c|c|c|c|}
\hline Item $^{1}$ & \multicolumn{2}{|c|}{ Normal starch } & \multicolumn{2}{|c|}{ Reduced starch } & SEM & \multicolumn{3}{|c|}{$P$-value ${ }^{2}$} \\
\hline \multicolumn{9}{|l|}{ FAB } \\
\hline${ }^{15} \mathrm{~N}$ atom $\%$ excess & 0.053 & 0.051 & 0.054 & 0.052 & 0.0033 & 0.49 & 0.18 & 0.73 \\
\hline \multicolumn{9}{|l|}{ PAB } \\
\hline NAN, \% of DM & 7.34 & 7.26 & 7.31 & 7.08 & 0.116 & 0.32 & 0.15 & 0.49 \\
\hline NAN, $\%$ of DM & 3.93 & 3.88 & 3.78 & 3.93 & 0.087 & 0.46 & 0.55 & 0.17 \\
\hline${ }^{15} \mathrm{~N}$ atom $\%$ excess & 0.049 & 0.048 & 0.049 & 0.048 & 0.0026 & 0.61 & 0.31 & 0.92 \\
\hline \multicolumn{9}{|l|}{ Large + small particle phase } \\
\hline NAN, $\%$ of DM & 4.49 & 4.55 & 4.19 & 4.48 & 0.118 & 0.03 & 0.04 & 0.16 \\
\hline${ }^{15} \mathrm{~N}$ atom $\%$ excess & 0.025 & 0.024 & 0.024 & 0.024 & 0.0013 & 0.50 & 0.50 & 0.92 \\
\hline
\end{tabular}

${ }^{1} \mathrm{FAB}=$ fluid-associated bacteria; $\mathrm{PAB}=$ particle-associated bacteria .

${ }^{2} \mathrm{ST}=$ starch; $\mathrm{PS}=$ particle size. 
Table 10. Effects of dietary starch content and corn particle size on ruminal $\mathrm{pH}, \mathrm{NH}_{3}-\mathrm{N}$ concentration, and VFA concentrations and molar proportions

\begin{tabular}{|c|c|c|c|c|c|c|c|c|}
\hline \multirow[b]{2}{*}{ Item } & \multicolumn{2}{|c|}{ Normal starch } & \multicolumn{2}{|c|}{ Reduced starch } & \multirow[b]{2}{*}{ SEM } & \multicolumn{3}{|c|}{$P$-value $\mathrm{e}^{1,2}$} \\
\hline & Fine & Coarse & Fine & Coarse & & ST & PS & $\mathrm{ST} \times \mathrm{PS}$ \\
\hline $\mathrm{NH}_{3}-\mathrm{N}, \mathrm{mg} / \mathrm{dL}$ & 5.86 & 6.60 & 6.98 & 6.81 & 0.402 & 0.12 & 0.49 & 0.28 \\
\hline Total VFA, $\mathrm{m} M$ & 87.4 & 97.6 & 92.3 & 95.1 & 4.31 & 0.78 & 0.13 & 0.38 \\
\hline \multicolumn{9}{|c|}{ VFA molar proportions, $\mathrm{mol} / 100 \mathrm{~mol}$} \\
\hline Acetate & 67.1 & 68.8 & 67.8 & 67.8 & 0.70 & 0.78 & 0.08 & 0.07 \\
\hline Butyrate & 10.0 & 9.4 & 9.6 & 10.0 & 0.26 & 0.55 & 0.71 & 0.07 \\
\hline 2-Methylbutyrate & 0.63 & 0.88 & 0.55 & 0.83 & 0.060 & 0.32 & $<0.01$ & 0.80 \\
\hline Isovalerate & 0.39 & 0.38 & 0.34 & 0.39 & 0.024 & 0.45 & 0.37 & 0.24 \\
\hline Valerate & 1.38 & 1.34 & 1.29 & 1.43 & 0.089 & 0.95 & 0.50 & 0.24 \\
\hline Acetate:propionate ratio & 3.42 & 3.70 & 3.47 & 3.65 & 0.118 & 0.97 & $<0.01$ & 0.37 \\
\hline
\end{tabular}

${ }^{1} \mathrm{ST}=$ starch; PS $=$ particle size.

${ }^{2}$ No effects for a diet $\times$ hour interaction $(P>0.25)$.

1997). However, the effect of grain particle size on rate of passage has been variable, resulting in both increased and decreased rates of passage out of the rumen (Nocek and Tamminga, 1991).

Baseline and mean serum insulin concentrations and AUC were unaffected by treatment, and we detected no interaction for treatment $\times$ time $(P>0.15$; data not provided). Baseline insulin concentrations were 268, 258, 238, and $270 \pm 53 \mathrm{pg} / \mathrm{mL}$ for NSFG, NSCG, RSFG, and RSCG diets, respectively. Mean insulin concentrations were $174,231,188$, and $196 \pm 56 \mathrm{pg} /$ $\mathrm{mL}$ and AUC values $(\mathrm{pg} \times \mathrm{mL} \times \mathrm{h})$ were $4,246,4,736$, 4,100 , and 4,349 \pm 860 for NSFG, NSCG, RSFG, and RSCG diets, respectively. Moriel et al. (2008) reported increased serum concentrations of insulin when highmoisture corn was fed compared with FG or CG dry corn in nonlactating cows, possibly because of greater rumen starch digestibility for high-moisture corn, which potentially led to greater ruminal propionate, hepatic blood flow, and gluconeogenesis (Huntington, 1997). However, comparisons between FG or CG corn did not affect serum insulin concentration (Moriel et al., 2008). Voelker and Allen (2003) found that partially replacing high-moisture corn with 12 or $24 \%$ beet pulp decreased plasma insulin concentrations in lactating dairy cows. However, the decrease may be attributable to a concomitant decrease in DMI when greater amounts of beet pulp were fed (Voelker and Allen, 2003). Lemley et al. (2010) also found that average plasma insulin AUC values were greater for cows fed corn starch compared with a high fiber diet containing soy hulls as the primarily replacement of corn starch, resulting from an increase in DMI and a potential increase in rumen propionate, and thereby leading to greater hepatic glucose synthesis. Although rumen propionate concentration was increased for the FG diet in the present study, similar DMI and ruminal starch digestibility across all diets may have resulted in similar serum insulin concentrations.

\section{CONCLUSIONS}

In the present experiment, milk yield was decreased for mid-lactation cows fed RS diets compared with NS diets. However, FCM was increased for cows fed the NSFG and NSCG diets. Furthermore, feeding RS and FG diets resulted in greater total-tract starch digestibility compared with NS and CG diets, whereas ruminal starch digestibility was increased only for cows fed the NS diets. Bacterial protein flow was unaffected by dietary treatments, but all estimates were likely overestimated because $\mathrm{N}$ flow was greater than $\mathrm{N}$ intake. The omasal and reticular sampling techniques resulted in similar treatment effects for nutrient flow and digestibility, suggesting that reticular sampling is a viable alternative to omasal sampling. Fat-corrected milk yields can be maintained or improved when RSCG diets are fed to mid-lactation cows. These results will further assist dairy farmers in identifying economically favorable dietary strategies when corn grain prices are increased.

\section{ACKNOWLEDGMENTS}

The authors thank Mike Peters and the staff at the Dairy Cattle Center (University of Wisconsin-Madison) for care and feeding of the animals used in the trial; Glen Broderick, Antonio Faciola, Wendy Radloff (all of US Dairy Forage Research Center, Madison, WI), and André Brito (University of New Hampshire, Durham) for technical advice; and Nurettin Gülșen (Selcuk University, Konya, Turkey), Elizabeth French, and Fernan- 
da Lopes (both of University of Wisconsin-Madison) for assistance during sample collections.

\section{REFERENCES}

Ahvenjärvi, S., A. Vanhatalo, P. Huhtanen, and T. Varvikko. 2000. Determination of reticulo-rumen and whole-stomach digestion in lactating cows by omasal canal or duodenal sampling. Br. J. Nutr. 83:67-77.

Akins, M. S., K. L. Perfield, H. B. Green, S. J. Bertics, and R. D Shaver. 2014. Effect of monensin in lactating dairy cows diets at 2 starch concentrations. J. Dairy Sci. 97:917-929.

AOAC International. 2012. Official Methods of Analysis. 19th ed. AOAC International, Arlington, VA.

Bach Knudsen, K. E. 1997. Carbohydrate and lignin contents of plant materials used in animal feeding. Anim. Feed Sci. Technol. $67: 319-338$.

Baker, S., and T. Herrman. 2002. Evaluating particle size. MF-2051. Kansas State Univ. Coop Ext. Serv., Manhattan, KS.

Bal, M. A., R. D. Shaver, A. G. Jirovec, K. J. Shinners, and J. G. Coors. 2000. Crop processing and chop length of corn silage: Effects on intake, digestion, and milk production by dairy cows. J. Dairy Sci. 83:1264-1273.

Brito, A. F., G. A. Broderick, and S. M. Reynal. 2006. Effect of varying dietary ratios of alfalfa silage to corn silage on omasal flow and microbial protein synthesis in dairy cows. J. Dairy Sci. 89:39393953.

Broderick, G. A., P. Huhtanen, S. Ahvenjärvi, S. M. Reynal, and K. J. Shingfield. 2010. Quantifying ruminal nitrogen metabolism using the omasal sampling technique - a meta analysis. J. Dairy Sci. 93:3216-3230.

Ferraretto, L. F., P. M. Crump, and R. D. Shaver. 2013. Effect of cereal grain type and corn grain harvesting and processing methods on intake, digestion, and milk production by dairy cows through a meta-analysis. J. Dairy Sci. 96:533-550.

Ferraretto, L. F., and R. D. Shaver. 2012. Meta-analysis: Effect of corn silage harvest practices on intake, digestion, and milk production by dairy cows. Prof. Anim. Sci. 28:141-149.

Ferraretto, L. F., R. D. Shaver, and S. J. Bertics. 2012. Effect of dietary supplementation with live-cell yeast at two dosages on lactation performance, ruminal fermentation, and total-tract nutrient digestibility in dairy cows. J. Dairy Sci. 95:4017-4028.

Ferraretto, L. F., R. D. Shaver, M. Espineira, H. Gencoglu, and S. J. Bertics. 2011. Influence of a reduced-starch diet with or without amylase on lactation performance by dairy cows. J. Dairy Sci. 94:1490-1499.

Firkins, J. L., M. L. Eastridge, N. R. St-Pierre, and S. M. Noftsger 2001. Effects of grain variability and processing on starch utilization by lactating dairy cattle. J. Anim. Sci. 79(E. Suppl.):E218 E238.

France, J., and R. C. Siddons. 1986. Determination of digesta flow by continuous marker infusion. J. Theor. Biol. 121:105-120.

Gencoglu, H., R. D. Shaver, W. Steinberg, J. Ensink, L. F. Ferraretto, S. J. Bertics, J. C. Lopes, and M. S. Akins. 2010. Effect of feeding a reduced-starch diet with or without amylase addition on lactation performance in dairy cows. J. Dairy Sci. 93:723-732.

Hoffman, P. C., N. M. Esser, R. D. Shaver, W. K. Coblentz, M. P. Scott, A. L. Bodnar, R. J. Schmidt, and R. C. Charley. 2011. Influence of ensiling time and inoculation on alteration of the starchprotein matrix in high-moisture corn. J. Dairy Sci. 94:2465-2474.

Holden, L. A. 1999. Comparison of methods of in vitro dry matter digestibility for ten feeds. J. Dairy Sci. 82:1791-1794.

Hristov, A. N. 2007. Comparative characterization of reticular and duodenal digesta and possibilities of estimating microbial outflow from the rumen based on reticular sampling in dairy cows. J. Anim. Sci. 85:2606-2613.

Huhtanen, P., S. Ahvenjärvi, G. A. Broderick, S. M. Reynal, and K. J. Shingfield. 2010. Quantifying ruminal digestion of organic matter and neutral detergent fiber using the omasal sampling technique in cattle - A meta-analysis. J. Dairy Sci. 93:3203-3215.
Huhtanen, P., P. G. Brotz, and L. D. Sattter. 1997. Omasal sampling technique for assessing fermentative digestion in the forestomach of dairy cows. J. Anim. Sci. 75:1380-1392.

Huhtanen, P., K. Kaustell, and S. Jaakkola. 1994. The use of internal markers to predict total digestibility and duodenal flow of nutrients in cattle given six different diets. Anim. Feed Sci. Technol. $48: 211-227$

Huntington, G. B. 1997. Starch utilization by ruminants: From basics to the bunk. J. Anim. Sci. 75:852-867.

Ipharraguerre, I. R., and J. H. Clark. 2003. Soyhulls as an alternative feed for lactating dairy cows: A review. J. Dairy Sci. 86:10521073.

Ipharraguerre, I. R., S. M. Reynal, M. Liñeiro, G. A. Broderick, and J. H. Clark. 2007. A comparison of sampling sites, digesta and microbial markers, and microbial references for assessing the postruminal supply of nutrients in dairy cows. J. Dairy Sci. 90:1904-1919.

Ipharraguerre, I. R., Z. Shabi, J. H. Clark, and D. E. Freeman. 2002 Ruminal fermentation and nutrient digestion by dairy cows fed varying amounts of soyhulls as a replacement for corn grain. J. Dairy Sci. 85:2890-2904.

Knowlton, K. F., M. S. Allen, and P. S. Erickson. 1996. Lasolocid and particle size of corn grain for dairy cows in early lactation. 2 . Effect on ruminal measurements and feeding behavior. J. Dairy Sci. 79:565-574.

Knowlton, K. F., B. P. Glenn, and R. A. Erdman. 1998. Performance, ruminal fermentation, and site of starch digestion in early lactation cows fed corn grain harvested and processed differently. J. Dairy Sci. 81:1972-1984.

Krizsan, S. J., S. Ahvenjärvi, H. Volden, and G. A. Broderick. 2010. Estimation of rumen outflow in dairy cows fed grass silage-based diets by use of reticular sampling as an alternative to sampling from the omasal canal. J. Dairy Sci. 93:1138-1147.

Krizsan, S. J., and P. Huhtanen. 2013. Effect of diet composition and incubation time on feed indigestible neutral detergent fiber concentration in dairy cows. J. Dairy Sci. 96:1715-1726.

Larson, J., and P. C. Hoffman. 2008. Technical note: A method to quantify prolamin proteins in corn that are negatively related to starch digestibility in ruminants. J. Dairy Sci. 91:4834-4839.

Lemley, C. O., T. A. Wilmoth, L. R. Tager, K. M. Krause, and M. E. Wilson. 2010. Effect of a high cornstarch diet on hepatic cytochrome P450 2C and 3A activity and progesterone half-life in dairy cows. J. Dairy Sci. 93:1012-1021.

Lopes, J. C., R. D. Shaver, P. C. Hoffman, M. S. Akins, S. J. Bertics, H. Gencoglu, and J. G. Coors. 2009. Type of corn endosperm influences nutrient digestibility in lactating dairy cows. J. Dairy Sci. 92:4541-4548.

Moriel, P., T. S. Scatena, O. G. Sá Filho, R. F. Cooke, and J. L. M. Vasconcelos. 2008. Concentrations of progesterone and insulin in serum of nonlactating dairy cows in response to carbohydrate source and processing. J. Dairy Sci. 91:4616-4621.

Nocek, J. E., and S. Tamminga. 1991. Site of digestion of starch in the gastrointestinal tract of dairy cows and its effect on milk yield and composition. J. Dairy Sci. 74:3598-3629.

NRC. 2001. Nutrient Requirements of Dairy Cattle. 7th rev. ed. Natl. Acad. Sci., Washington, DC.

Rémond, D., J. I. Cabrera-Estrada, M. Champion, B. Chauveau, R. Coudure, and C. Poncet. 2004. Effect of corn particle size on site and extent of starch digestion in lactating dairy cows. J. Dairy Sci. 87:1389-1399.

Reynal, S. M., and G. A. Broderick. 2005. Effect of dietary level of rumen-degraded protein on production and nitrogen metabolism in lactating dairy cows. J. Dairy Sci. 88:4045-4064.

Richards, C. J., J. F. Peterson, R. A. Britton, R. A. Stock, and C. R. Krehbiel. 1995. In vitro starch disappearance procedure modifications. Anim. Feed Sci. Technol. 55:35-45.

Robinson, P. H., and J. J. Kennelly. 1990. Evaluation of a duodenal cannula for dairy cattle. J. Dairy Sci. 73:3146-3157.

Siddons, R. C., J. Paradine, D. E. Beever, and P. R. Cornell. 1985. Ytterbium acetate as a particulate-phase digesta-flow marker. Br. J. Nutr. 54:509-519. 
Supelco. 1998. Analyzing fatty acids by packed column gas chromatography. Technical Bulletin \#856B. Supelco Inc., Bellefonte, PA.

Tassoul, M., R. Shaver, J. Barmore, D. Taysom, and P. Hoffman. 2007. Laboratory evaluation of corn grain and silage digestibility. Prof. Anim. Sci. 23:702-708

Taylor, C. C., and M. S. Allen. 2005. Corn grain endosperm type and brown midrib 3 corn silage: Ruminal fermentation and N partitioning in lactating cows. J. Dairy Sci. 88:1434-1442.

Udén, P., P. E. Colucci, and P. J. Van Soest. 1980. Investigation of chromium, cerium and cobalt as markers in digesta. Rate of passage studies. J. Sci. Food Agric. 31:625-632.
Van Soest, P. J., F. B. Robertson, and B. A. Lewis. 1991. Methods for dietary fiber, neutral detergent fiber, and nonstarch polysaccharides in relation to animal nutrition. J. Dairy Sci. 74:3583-3597. Voelker, J. A., and M. S. Allen. 2003. Pelleted beet pulp substituted for high-moisture corn: 1. Effects on feed intake, chewing behavior, and milk production of lactating dairy cows. J. Dairy Sci. 86:3542-3552

Yu, P., T. Huber, F. A P. Santos, J. M. Simas, and C. B. Theurer. 1998. Effects of ground, steam-flaked, and steam-rolled corn grains on performance of lactating cows. J. Dairy Sci. 81:777-783. 